\title{
Tax Administration Information Systems
}

\section{Concept, Design, and Implementation}

by David Tansey

\section{Introduction}

In the past few years, international organizations including the Asian Development Bank (ADB), have partnered with other associations and platforms, such as the Addis Tax Initiative, to improve domestic revenue mobilization (DRM) to provide governments with resources that are needed to meet sustainable development goals and lift their populations out of poverty.

Improvements to tax systems can take the form of improved laws, administrative practices, and training programs. This brief focuses on an improved tax administration information system (TAIS) for tax authorities. This includes the TAIS basic administration machinery that interfaces to allow taxpayers to register, file, and provide pay electronically; data warehouses; data matching; internal control functions; and management information systems.

An improved TAIS allows a level of transparency that flows onto other agencies and to the government. For example, a high net wealth individual unit in a tax authority that effectively operates can detect wealth gains by corrupt civil servants, politicians, and criminals, and help bring these people to justice. Tax authorities can provide information to, or conduct joint operations with, police and other government departments such as those handling social security payments and government contracts.

\section{Benefits of Information and Communication Technology in Tax Administration}

Tax authorities sometimes use the reinvigoration of their information and communication technology (ICT) systems as a driver of transformation. There are two options:

(i) implementation of a new in-house solution (a bespoke or custom-built system), developed by staff or a service provider; or

(ii) procurement of a commercial off-the-shelf (COTS) product to replace the system that is to be discontinued.

Governments can fund a new TAIS for the tax authority, but they may lack the resources or political

\footnotetext{
David Tansey is a freelance consultant in tax administration and policy. He spent 19 years in the Australian Taxation Office and 15 years as a consultant in several developing and transition economies. In 2017, he was an ADB consultant in the Governance Thematic Group, Sustainable Development and Climate Change Department.
}

For inquiries, comments, and suggestions, please contact the editor of the Governance Brief, Claudia Buentjen, at +6326831852 or cbuentjen@adb.org, SDCC Thematic Advisory Service Cluster, Governance Thematic Group. Previous issues of The Governance Brief can be accessed at http://www.adb.org/ publications/series/ governance-briefs. 
International lenders and donors may step in to fund the renewal of ICT systems of tax authorities. will to do so. In the first case, international lenders and donors may step in to fund the renewal of ICT systems of tax authorities. It is critical that correct decisions are made on whether to use a COTS or a bespoke system and that good decisions are made in procurement, consultant recruitment, business process mapping, project management, change management, and internal and external communication to ensure the efficient and effective use of funds.

Making the right decisions can lead to outcomes that increase domestic revenues, reduce corruption in the revenue authority, reduce fraud opportunities in the taxpaying community, and provide assurance to the government that the tax authority is being properly managed. Well-governed tax authorities should be a priority for donors with limited resources to target countries for the most efficient and effective use of resources, with the aim of maximizing DRM and lifting people out of poverty.

A United States Agency for International Development report recommends four main capabilities of technology solutions for tax administrations:

(i) A core tax system provides support, automation, workflow management, and authorization management to tax administration functions;

(ii) An e-tax system provides information, education, and support to taxpayers and facilitates compliance and administration;

(iii) A compliance performance system deploys risk-based procedures to detect and deter noncompliance; and

(iv) A management information system facilitates the collection and dissemination of performance information to staff and management. $^{2}$

If either a COTS or a bespoke system is considered, it is assumed that the current system (called the legacy system, after the new system has been implemented) has been determined as too outdated or beyond repair to effectively support the business.

A bespoke system requires the development of a new software. An external firm may be engaged to develop a program according to the tax authority's requirements. The business functionality needs to be documented as a set of requirements, the complexity of which, such as the data size, number of users, and other factors, is to be costed by ITC experts. The new modules can be implemented in a

\section{Table 1: Benefits of an Improved Tax Administration Information System}

\begin{tabular}{|c|c|}
\hline Benefit & Specific Gains for Domestic Resource Mobilization \\
\hline $\begin{array}{l}\text { Greater potential } \\
\text { for revenue } \\
\text { mobilization }\end{array}$ & $\begin{array}{l}\text { Return on investment in additional tax revenue is several times the cost of the new } \\
\text { system. } \\
\text { Sustainable support is provided for administrative systems and revenue growth. }\end{array}$ \\
\hline Efficiency & $\begin{array}{l}\text { Greater efficiency across all functions, including those with direct relevance to } \\
\text { increasing domestic revenue mobilization: } \\
\text { - enhanced risk management for better audit case selection } \\
\text { - better ability to detect fraudulent tax refunds } \\
\text { - ability for the tax authority to view the taxpayer in an integrated way across all tax } \\
\text { types } \\
\text { - reduction in taxpayer compliance costs and agency costs }\end{array}$ \\
\hline Transparency & $\begin{array}{l}\text { Unique user identification with attached audit log of transactions ensures } \\
\text { accountability. } \\
\text { Use of discretionary powers must be within parameters that the system can monitor. } \\
\text { Documents are stored on system electronically and provide an evidentiary record. } \\
\text { Internal control systems contain alerts when unusual behavior by an individual is } \\
\text { detected. }\end{array}$ \\
\hline Governance & Improved management information reporting assists management decision-making. \\
\hline
\end{tabular}

Source: Author.

2 G. Jimenez et al. 2013. Information Technology for Tax Administration. USAID's Leadership in Public Financial Management. p. 8. 
phased approach over time to reduce the cost of a large one-off development or purchase.

On the other hand, a COTS product requires procurement from a firm. Over a dozen companies sell proprietary tax administration COTS, either as part of or as the entirety of their business. These products may be used at either the national or subnational levels of government administration.

The COTS product will have an out-of-the box functionality that is immediately operational after being configured (e.g., each country has its own tax rates and thresholds) and other parts that need to be customized (adjusted to the unique specifications of the tax authority's business processes). The less that the COTS product needs to be customized, the better, as this reduces the costs of implementation and of rolling out subsequent upgrades. In some cases, business processes might benefit from being adapted to the software available-contrary to the old saying that the business should drive the ICT.

\section{Strategy Development}

There are some small Pacific island countries with a handful of staff in their tax administration and a few dozen taxpayers. In this case, the appropriate
ICT support for the tax administration may be a commercially available spreadsheet.

The basic driver of decision-making on ICT is improved support for a more efficient tax administration which can optimize DRM, all other factors being equal (government support, agency staff skills, transparency, and public goodwill).

The decision tree for the tax authority starts with an initial question: do we want to change our existing ICT systems in a major way? Major changes do not refer to regular upgrades and maintenance done as a matter of course as the law changes, new channels for communication come on the market, or new hardware is developed.

The answer should be based on a thorough review of the current systems, how well they support business needs, predictable requirements, measurement of the tax gap, availability of donor assistance, cost-benefit analysis, and other relevant factors. Would dispersed systems benefit from integration? Is the technological infrastructure in place (e.g., bandwidth) to extend systems across large land areas and archipelagos?

If the answer is no, then the management should be committed to the existing systems and the issues and costs (including revenue shortfalls) that come with them. Incremental improvements can still be made to existing systems through
The basic driver of

decision-making on ICT is improved support for a more efficient tax administration which can optimize domestic resource mobilization.

Figure 1: Decision Tree on Information and Communication Technology Systems Change

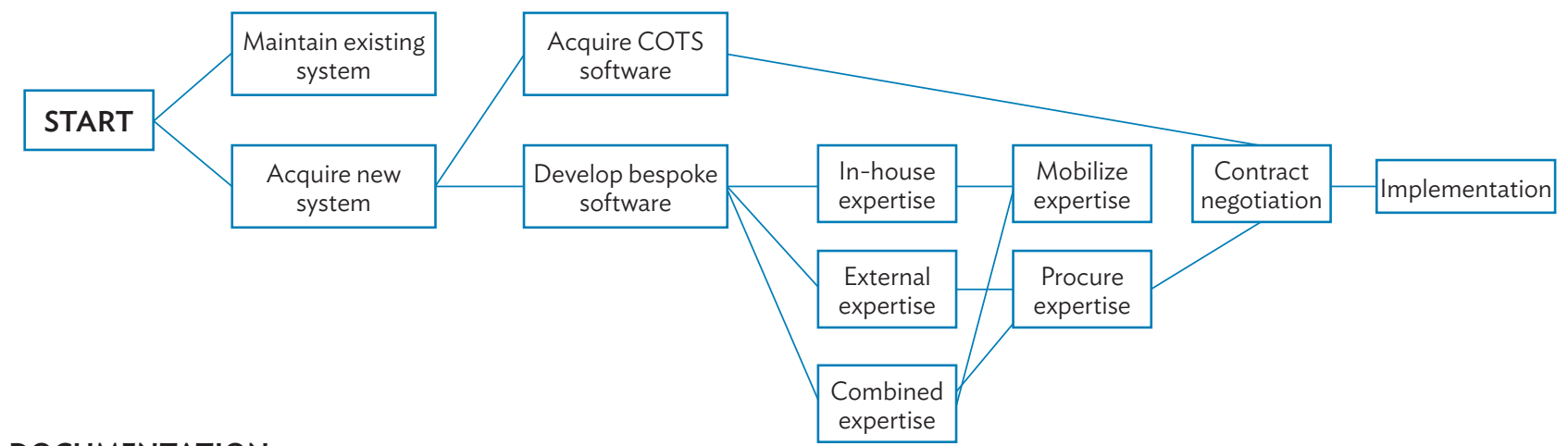

DOCUMENTATION

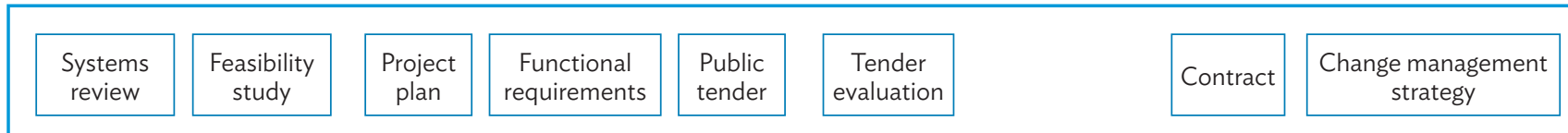

COTS = commercial-off-the-shelf.

Source: Author. 
The new ICT system should be designed in such a way as to provide a return on investment several times over, through a sustained increase in domestic revenue. enhancements, new interfaces (such as with social media), and new opportunities to match data with external agencies.

If the answer is yes, the next decision point is whether to purchase a COTS product or to develop a bespoke system. This decision is a very complex one. Do the business processes have rules that have existed for decades for no apparent reason? Should those processes be abandoned? Have studies been done on reverse workflows, efficient handover of tasks from one unit to another, simplification of processes, and reduction in costs for the government and the taxpayer? Has the tax authority developed solutions on a case-by-case basis over the years so that it now has many systems which would benefit from being integrated?

The ICT expert should lead the investigation. A review of business processes should be conducted, and recommendations for improvements suggested, before the preferred design is put out to tender.

Many inefficiencies within tax business processes result from poor law design. A review of business processes should involve the review of the laws underlying each process; collection of all forms, documents, manuals, website instructions related to the processes; and observation of users processing an actual transaction, such as registering a new taxpayer, or entering data from a tax return. The analyst should then prepare a flow chart and a description of how a business process operates, and make recommendations for streamlining, removal of reverse workflows, reduced compliance costs, increased use of new technology, more efficient handovers from one unit to another, and other logical improvements.

In the case of a new system not being adopted, the issue of how to make system changes as the tax law evolves is still present. This may be something that happens once a year, or several times a year. As older systems continue to tick over, the ability to modify them becomes more difficult and more expensive. As law changes are often outside the power of the tax authority, it may be necessary to implement a software that supports inefficient business processes based on poor law design.

\section{Design}

The new ICT system should be designed in such a way as to provide a return on investment several times over, through a sustained increase in domestic revenue. This is achieved through simple and personalized taxpayer service mechanisms, effective compliance controls, and effective internal controls.

\section{Box: Example of Improved Business Processes}

\section{Current practice:}

When a new taxpayer comes to the tax office to register, the tax office creates a pro forma registration in the system. Business license information is received from a weekly data transfer from another government agency that issues business registrations. When this is received, the tax registration is formalized by the tax authority. While the tax registration is pro forma, the actions of the taxpayer are limited, e.g., they cannot file a return. Sometimes the data from the business registry are received late, and at times (about 5\%) the business registration data do not match those provided on the new tax registration form, requiring an investigation to determine the "real" data and correct the record.

\section{Recommended practice:}

Processes should be self-contained within the tax authority and not depend on actions taken by another government agency. When a new taxpayer comes to the tax office to register, the taxpayer provides identity documents and a hard copy of the business registration from the business registration agency. This is accepted at face value, as 95\% are correct. Data from the business registration office is later received and matched. Any data discrepancy is investigated and corrected either in the tax record or the business registration record as appropriate. The external data matching does not impact the newly registered taxpayer's ability to file, pay, and perform other tax functions (although tax refunds are stopped in the period until the registration data is verified).

Source: Author. 
Compliance controls include taxpayer-facing areas and backroom functions. Tax compliance functions that are taxpayer-facing comprise the following:

(i) Audit. This is a detailed examination of the financial affairs of the taxpayer's income tax affairs, or a detailed examination of business documentation for value-added tax purposes. Audits can be field-based or desk-based, random, focus on specific items, or use indirect income measurement techniques. Some audits can focus on specific technical issues or be industry-based.

(ii) Investigation. This involves an examination of whether the taxpayer has committed an offense under the tax laws, which should be brought to court.

(iii) Appeals. Where a taxpayer disputes an assessment, the process usually involves an administrative review before proceeding to a court. Alternative dispute resolution can save both parties time and legal costs.

Backroom processes for ensuring tax compliance comprise the following:

(i) Risk analysis. This usually involves a systemsdriven process where the risk engine is programmed with risk factors based on benchmarks with industry turnover levels, industry code, individual taxpayer history, and dozens of other factors. The system attaches a risk rating to every registered taxpayer.

(ii) Intelligence. This involves the process of adding value to information, which helps to achieve business goals. In the tax context, this can comprise individual and industry assessments, information from other government agencies and third parties, information from public hotlines and whistleblowers, social media, and many other sources.

(iii) Case selection. The case selection area selects cases for audit or investigation, based on intelligence and risk analysis. This may be part of the system's audit module.

Additional dimensions to the compliance function may include the following:

(i) Large taxpayer unit. This unit is dedicated to monitoring the compliance of a relatively few large corporations, entities, and groups (usually in the hundreds), which should contribute about $70 \%-90 \%$ of total revenue.

(ii) Medium taxpayer unit. This unit is dedicated

Figure 2: Typical Tax Administration Functions (Taxpayer-Facing and Backroom)

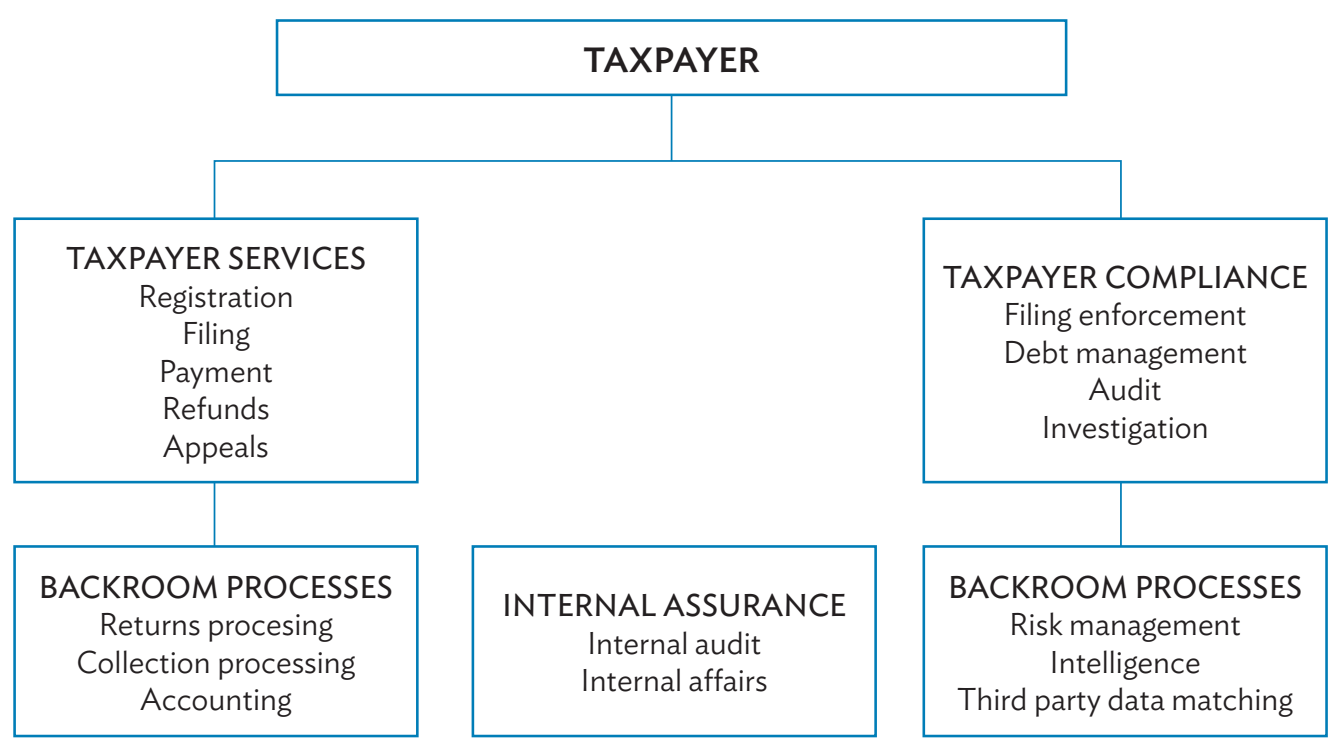

Source: Author. 
The system should

have interfaces to

allow taxpayers to

conduct routine

transactions

(such as filing and

payment) online. to monitoring the compliance of the next significant group of taxpayers who are not large taxpayers but still have significant size of turnover, assets, or employees.

(iii) Micro, small, and medium-sized businesses. There are numerous businesses that provide a relatively small share of total revenue and are dealt with under general service and compliance functions.

(iv) High net worth individual unit. This unit is dedicated to monitoring wealthy individuals (defined as people with net worth of $€_{30}$ million in Europe, but in developing countries may be adjusted to reflect patterns of general national wealth).

The system should provide certainty to the public through transparent rules, discretion exercised within known parameters, and a nosurprises principle. Public education campaigns should be conducted on topical issues, and up-todate educational material published on the agency website.

The system should have interfaces to allow taxpayers to conduct routine transactions (such as filing and payment) online. A 2013 study by ADB shows that many tax authorities in the Asia and Pacific region provide e-services to taxpayers. ${ }^{3}$

\section{Integrity Benefits from New Information and Communication Technology Systems}

The renewal of ICT systems opens the opportunity for integrity improvement. The tax authority should have a dedicated internal affairs unit that reports directly to the head of the authority, and has secure functionality within the ICT systems. Whistleblower protection should also be provided for in the law and the authority's governance rules for tax officials and members of the public.

At a minimum, all transactions in the system should be recorded in an audit log within the system, with the user identification of the person making the transaction recorded, along with the date and time of the transaction. Data both before and after the transaction should be stored. The internal affairs staff should have unfettered access to the audit log, and no one else.
The system should provide a series of alerts to the internal affairs unit when an unusual transaction takes place. A single alert does not mean that action should be taken. A pattern of alerts against one tax official can build up a picture of that person's activity and may require possible intervention.

Examples of transactions that should trigger alerts are:

(i) the medium duration of the taxpayer interactions (call, visit, and online) constantly exceeds the standard in case of a certain tax officer or team within a determined period (e.g., monthly);

(ii) an application for registration is approved without full documentation;

(iii) a taxpayer who has not submitted tax returns or has unpaid tax debts is deactivated;

(iv) a taxpayer is reactivated with full rights although it has unpaid tax debts;

(v) the tax officer decision to reimburse and/or refund or not, against the recommendation of the system;

(vi) a manual intervention has been made on a default return;

(vii) the same tax officer is assigned repeatedly to cases that involve the same taxpayer within a defined period;

(viii) the same tax officer is allocated for the control of the same taxpayer, over a certain period;

(ix) a case is opened without risk analysis or referrals from other departments;

(x) the tax officer assigned to resolve an appeal has been involved in issuing the contested decision;

(xi) manual overrides are made to the taxpayer's risk scoring; and

(xii) the duration of a fraud control is too short (for example, less than 3 days for simple controls, less than 10 days for complex controls).

Apart from internal control, there are other ways that a new ICT system can enhance integrity.

One way is to minimize the interaction of taxpayers and the tax authority staff is through electronic channels. This could include informative websites, electronic filing of returns, electronic payments, and secure email communication to a dedicated private virtual space. Taxpayers should be

3 ADB. 2013. Electronic Taxpayer Services in Asia and the Pacific. Manila. 
able to transmit documents electronically to provide a record of all communications. The tax authority should scan incoming paper documents and attach them to the taxpayer record.

Electronic interaction, and the document trail, can eliminate the need for face-to-face meetings between a taxpayer and a tax official, where the tax official may use discretionary powers in an improper manner. All transactions and communications between official and taxpayer can be recorded in the database, and have evidentiary value in a proceeding. Taxpayers can attach PDF documents such as invoices to their tax records to support their claims for deductions and credits.

The link between integrity and tax effort was described in a paper by the International Monetary Fund (IMF) presented at an ADB-Asian Development Bank Institute conference in Sydney in April 2017 titled Tax and Corruption. The paper mapped the tax and gross domestic product ratio of all countries against the Transparency International survey on perceived corruption.

The study found that: "The effect of corruption is statistically significant: it shows that, all else equal, an improvement in a country's corruption perception indicator by one standard deviation (22 points) is associated with a tax revenue increase of 0.88 percentage point of GDP." ${ }^{4}$

\section{Procurement}

Procurement should be conducted according to the rules of the donor organization, based on a documented set of business requirements, and ICT requirements. A two-stage tender process allows potential vendors to submit an initial proposal, and later a second and final one after clarifications to questions from the tender evaluation committee. The tender evaluation might include open forums to discuss requirements, one-on-one meetings with the authority and the vendor, and site inspections of other countries where the vendor's product has been successfully installed.

The business requirements should be based on a review of business processes, which will highlight gaps between current and required practices. Because laws and business processes are constantly changing, it is necessary to produce requirements at a fixed date, even though they may out of date the following week. Fixed requirements are used as the basis for issuing tenders and for the successful tenderer to configure their COTS or program the new system accordingly. The longer the procurement process drags out, the more the requirements become outdated and costs accrue.

COTS products have been used extensively in developing nations throughout the world, including
Electronic interaction, and the document trail, can eliminate the need for faceto-face meetings between a taxpayer and a tax official.

\section{Table 2: Phases in the Introduction of a Commercial Off-the-Shelf Product Over Five Years}

\begin{tabular}{|c|c|c|c|c|}
\hline Year & $1-2$ & $2-3$ & $3-4$ & $4-5$ \\
\hline Pre-Project & Project Initiation & Procurement & Implementation & Post-Project \\
\hline $\begin{array}{l}\text { - Investigation into } \\
\text { ICT needs of DMC } \\
\text { - Decision by donor to } \\
\text { fund ICT renewal } \\
\text { - Tax authority } \\
\text { to undertake } \\
\text { groundwork and } \\
\text { appoint project } \\
\text { champion }\end{array}$ & $\begin{array}{l}\text { - Appoint project } \\
\text { manager } \\
\text { - Establish project } \\
\text { office } \\
\text { - Develop project plan, } \\
\text { strategies, and risks } \\
\text { - Review business } \\
\text { processes and } \\
\text { document } \\
\text { requirements } \\
\text { - Review ICT } \\
\text { requirements }\end{array}$ & $\begin{array}{l}\text { - Establish tender } \\
\text { board } \\
\text { - Establish selection } \\
\text { criteria } \\
\text { - Issue two-stage } \\
\text { tender document } \\
\text { - Review stage } 1 \\
\text { tenders and respond } \\
\text { - Review stage } 2 \\
\text { tenders } \\
\text { - Decide on tender } \\
\text { - Contractual process }\end{array}$ & $\begin{array}{l}\text { - Change management } \\
\text { strategy in place } \\
\text { - Vendor's staff to } \\
\text { colocate with tax } \\
\text { authority staff } \\
\text { - Delivery of out-of- } \\
\text { the-box functionality } \\
\text { - Customization of } \\
\text { - other functionality } \\
\text { - Systems testing } \\
\text { "Cut-over" from old } \\
\text { to new system }\end{array}$ & $\begin{array}{l}\text { - Transfer of } \\
\text { ownership from } \\
\text { vendor to tax } \\
\text { authority ICT staff } \\
\text { - Post-implementation } \\
\text { review } \\
\text { - Fine-tuning of ICT } \\
\text { within warranty } \\
\text { period } \\
\text { - Ongoing } \\
\text { maintenance and } \\
\text { systems change } \\
\text { process in place }\end{array}$ \\
\hline
\end{tabular}

$\mathrm{DMC}=$ developing member country, ICT = information and communication technology.

Source: Author.

\footnotetext{
4 IMF. 2017. Corruption: Costs and Mitigating Strategies. Paper presented by Sanjeev Gupta, at the Tax and Corruption: An Asia-Pacific Perspective Conference. Sydney. 13-14 April.
} 


\section{The criteria for deciding on COTS}

procurement or developing a bespoke system depend on the technical and management capabilities of the tax authority, the level of funding, and the strategic objectives of the organization.
Asia and the Pacific, South America, and Africa. They have been used at the subnational level in the United States. In Europe, COTS has only been implemented in one country at the time of writing (Kosovo) and was in the process of being implemented in two countries (Finland and Poland). Tenders in progress for procurement of COTS in Romania and Slovenia are ongoing. New Zealand is currently implementing a COTS solution, with minimal customization.

Mongolia recently announced that it was abandoning its attempt to implement a COTS and was looking at developing a bespoke system through the state-owned enterprise that administers tax and customs ICT. COTS has been implemented successfully in Maldives, Papua New Guinea, and Timor-Leste.

In Finland, an unsuccessful tenderer sued the government, which delayed the implementation of the COTS by the successful tenderer by a year. The unsuccessful tender was excluded as being "abnormally low" and "not realistic."

While each COTS solution has its relative strengths and weaknesses, all products have been quality tested by tax and ICT experts and improved through implementation experiences. The procurement decision should be based on the extent to which the systems' functionality can support the business requirements of the tax authority, after minimal customization. The design features of each option is very much the same.

The criteria for deciding on COTS procurement or developing a bespoke system depend on the technical and management capabilities of the tax authority, the level of funding, and the strategic objectives of the organization.

An ADB report describes four levels of automation for the functions and services that might be delivered under a tax ICT system, as described in Table 3.

The KfW report recommends that the following should be asked first:

(i) What kind of an organization does the tax administration want to become?

(ii) What should the interaction with taxpayers look like?

(iii) What is the relation with the wider governmental strategy?

The KfW report suggests that the capability framework of the tax authority should be mapped, then each system on offer assessed against this and rated using a scoring system of $\mathrm{O}=$ no functionality, $1=$ very limited functionality, 2 = functionality available with some limitations, 3 = full functionality (footnote 6).

The IMF report (footnote 4) advises: "Purchasing a COTS product creates a long-term

\section{Table 3: Four Levels of Automation Under a Tax Administration Information System}

\begin{tabular}{|c|l|}
\hline Level & \multicolumn{1}{c|}{ Description } \\
\hline 1 & The functions and services in the tax administration lifecycle have not been automated. \\
\hline 2 & $\begin{array}{l}\text { A preliminary level of automation is in place where the primary focus is digitizing the data } \\
\text { after the completion of the transaction. The overall objective is to create the electronic } \\
\text { database for generating useful management information system reports. }\end{array}$ \\
\hline 3 & $\begin{array}{l}\text { This level primarily focuses on automating the transactions internally with no or minimal } \\
\text { physical interface with taxpayers. Only the staff of the tax agency have access to the system. }\end{array}$ \\
\hline 4 & $\begin{array}{l}\text { An advanced level of automation where services and functions related to tax administration } \\
\text { are automated with minimal interaction with the taxpayers. There are also provisions for } \\
\text { exchanging data with other external stakeholders such as banks. }\end{array}$ \\
\hline
\end{tabular}

Source: Asian Development Bank. 2014. Tool Kit for Tax Administration Management Information System. Manila. p. 13.

\footnotetext{
5 Greg. 2013. Finland Rejects IBM's "Abnormally Low" Offer for New Tax System, Selects Finnish-Estonian Nortal. ArcticStartUp. 15 May. http://arcticstartup.com/article/finland-tax-nortal-ibm/.

$6 \mathrm{KfW}$ Development Bank. 2015. Information Technology in Tax Administration in Developing Countries. Frankfurt.
} 
arrangement with the vendor. As with any long-term relationship, care must be taken to manage the arrangement and any issues which develop need to be resolved, both quickly and effectively. The abilities of and relationships with vendor-supplied experts are essential to a successful outcome."

The advantages and disadvantages of each option are shown in Table 4.

\section{Implementation}

In anticipation of the new ICT system, the tax authority needs to establish a project office with staff who will engage in the procurement, planning, change management, and other functions to support all phases of the implementation. The composition and size of the project office will evolve depending on the time frame to implement the solution. The project office needs to be led by a senior officer and must have a project champion in the senior ranks (probably second to the tax office head) who has a combination of both management and tax technical skills.

The project office needs to be distinguished from the project team, which will conduct the actual implementation of the new system. The project office is a long-term support function with corporate memory. The staff need to be skilled in project planning, strategic planning, change management, risk management, scheduling, training, and communications.
The project team will be composed of staff members from the ICT and business areas of the tax authority, either on a full-time or part-time basis. The fact that they will be away from their usual workplace to work on the new system needs to be recognized as a cost.

The vendor will require office space in the tax authority for a large number of its staff and the resources to support them. The vendor's team leader and the tax authority's project manager should work closely together and have an open communication channel.

Change management is a vital support function to ensure the transition from the old system to the new one. Neglect of change management is one of the major causes of failure of implementing new systems; it is not a luxury or something that can be added to someone else's work.

The review of business processes should identify where processes can be improved in three situations:

(i) improvements that require both law and systems changes,

(ii) improvements that require either a law or systems change, and

(iii) improvements that require neither a law or systems change.

Improvements that do not require a law or systems change should be brainstormed with operative staff from each division and filtered to arrive at a "quick wins" program of change, to get
In anticipation of

the new ICT system, the tax authority needs to establish a project office with staff who will engage in the procurement, planning, change management, and other functions to support all phases of the implementation.

\section{Table 4: Pros and Cons of a Commercial Off-the-Shelf Solution and a Bespoke System}

\begin{tabular}{|c|c|c|}
\hline Item & Commercial Off-the-Shelf Solution & Bespoke System \\
\hline Advantages & $\begin{array}{l}\text { - High quality, fully integrated } \\
\text { - Built-in best practice for business } \\
\text { functionality } \\
\text { - Shorter implementation time }\end{array}$ & $\begin{array}{l}\text { - A tailored solution for the } \\
\text { organization's needs } \\
\text { - Lower initial cost } \\
\text { - Leverages internal expertise }\end{array}$ \\
\hline Disadvantages & $\begin{array}{l}\text { - Customization leads to complexity } \\
\text { and cost for upgrades } \\
\text { - Higher initial costs } \\
\text { - Dependence for maintenance on an } \\
\text { external provider }\end{array}$ & $\begin{array}{l}\text { - Level of change management and } \\
\text { project management expertise may } \\
\text { not exist in-house } \\
\text { - Difficult to retain key information } \\
\text { technology staff } \\
\text { - Longer implementation time }\end{array}$ \\
\hline
\end{tabular}

Source: Author.

M. Cotton and G. Dark. 2017. Use of Technology in Tax Administrations 3: Implementing a Commercial off-the-Shelf (COTS) Tax System. Technical Notes and Manuals No. 17/3. Washington, DC: International Monetary Fund. p. 9. 


\section{Investment in ICT \\ renewal of tax}

authorities can result

in a more efficient

administration. the organization and the public to support the overall change program.

An important and underestimated area of change is that of forms design. Tax forms and standard letters should be redesigned to be user-friendly, clear, simple, and less bureaucratic. In redesigning forms and letters, the principles of behavioral economics should be observed. (See behavioraleconomics.com/the-be-guide/.)

The appointment of "super-users" from business operational areas, who will receive a detailed level of training and assist others during the implementation, is essential to overall project success. These people should be identified at an early stage and be given information about the progress of the new system at regular intervals.

The project needs a champion from the upper ranks of the tax authority hierarchy, usually someone second to the commissioner, to smooth out any bumps on the road at a high level. Communications from the champion on a regular basis through the usual communication channels of the tax authority will inform the general tax authority staff of the project's implementation.

\section{Conclusion}

Investment in ICT renewal of tax authorities can result in a more efficient administration. Other benefits may include better internal controls and increased transparency in the tax authority and, to a greater extent, in the country. As such projects require large investments, and have significant impacts upon the tax administration and the wider community, risk and change must be effectively managed. Decision-making needs to be controlled, and strategic planning for the project carefully overseen.

The decisions to be made are whether to renew the ICT, whether to use a COTS or bespoke solution, and what criteria to base the procurement on. The business processes of the tax authority need to be reviewed and modified before the functional requirements for the new system are put out to tender.
ADB has had a generally successful record in tax projects, including on the improvement of the TAIS of various tax authorities.

This Governance Brief was peer-reviewed by Yuji Miyaki, public management specialist (taxation), and Yasushi Suzuki, public management specialist (taxation).

\section{Suggested Reading}

Asian Development Bank. 2014. A Review of Governance e-Solution Investments, 2004-2012. Manila. https://www.adb.org/documents/reviewgovernance-e-solution-investments-2004-2012.

- - 2014. Tool Kit for Tax Administration Management Information System. Manila. http://hdl. handle.net/11540/5105.

M. Cotton and G. Dark. 2017. Use of Technology in Tax Administrations 3: Implementing a Commercial off-the-Shelf (COTS) Tax System. Technical Notes and Manuals No. 17/3. Washington, DC: International Monetary Fund. https://www.imf. org/en/Publications/TNM/Issues/2017/03/15/ Use-of-Technology-in-Tax-Administrations-3Implementing-a-Commercial-Off-The-ShelfCOTS-Tax-44719.

Z. Hasnain et al. 2016. Does e-government improve government efficiency? Evidence of tax administration and public procurement. World Bank Policy Research Working Paper. No. 765. Washington DC: World Bank. http://documents. worldbank.org/curated/en/334481468193734893/ pdf/WPS7657.pdf.

G. Jimenez et al. 2013. Information Technology for Tax Administration. USAID's Leadership in Public Financial Management. https://pdf.usaid.gov/pdf_ docs/pnaea485.pdf.

KfW Development Bank. 2015. Information Technology in Tax Administration in Developing Countries. Frankfurt. https://www.taxcompact.net/ documents/IT-Tax-Administration-Study.pdf.

Creative Commons Attribution 3.0 IGO license (CC BY 3.0 IGO)

(C) 2019 ADB. The CC license does not apply to non-ADB copyright materials in this publication.

https://www.adb.org/terms-use\#openaccess http://www.adb.org/publications/corrigenda

ISBN 978-92-9261-658-8 (print), 978-92-9261-659-5 (electronic) pubsmarketing@adb.org

ISSN 2520-6591 (print), 2520-6605 (electronic)

Publication Stock No. BRF190225

https://www.adb.org/publications/series/governance-briefs

DOI http://dx.doi.org/10.22617/BRF190225 